\title{
The researcher's view: context is critical
}

\author{
Sheila Corrall and Ray Lester
}

\section{Introduction}

Our ideas about future models of the library focus on the needs of researchers. Our thinking is informed by our own experiences as both users and directors of library and information services in research institutions, and by debates on future roles for library and information professionals in the network world - a world where automation, digitization and socialization of data, information and knowledge, and disintermediation, are transforming the scholarly landscape. We begin with three reasons why library support for research is a critical issue, and then reflect on the current situation and environmental forces shaping provision for researchers, before setting out our thoughts about future services and spaces for research.

\section{The library and research}

First, higher education institutions across the globe continue to identify teaching and research as two distinct missions (Scott, 2006), and most academic libraries similarly define their roles in education and research as related, but separate, elements of their mission (Aldrich, 2007). Second, surveys in several countries show that researchers' experiences and perceptions of libraries are not altogether positive (Daniels, Darch and de Jager, 2010; Schonfeld and Housewright, 2010; MacColl and Jubb, 2011) and their views about future priorities often differ from librarians' views (RIN, 2007). Third, while changes in teaching and learning have largely driven spatial transformations of academic libraries over the past 20 years, we expect changes in research and scholarship to have a more central role over the next two decades in transforming and re-engineering libraries to meet the needs of both researchers and learners (Lyon, 2012). 


\section{Current provision and usage}

For most people, the idea of a library is inseparable from a collection of books and periodicals, a perception that has continued into the network world, despite the arrival of digital technologies, new media and online services. Library requests for research assistance have given way to self-help and mutual support; few people use ask-alibrarian services and information seekers rarely start their search on library websites (OCLC, 2010). Academic researchers mainly use electronic resources, which they access remotely, with only arts and humanities researchers visiting libraries regularly, but less often than before (RIN, 2007). Faculty members rarely consult a librarian or use the library catalogue to begin their research, preferring network-level services, including general-purpose search engines, as well as services targeted at academics (Schonfeld and Housewright, 2010).

Library services for research range from the simply reactive to highly creative (Webb, Gannon-Leary and Bent, 2007), but most researchers seem to have little interest in the support offered (MacColl and Jubb, 2011). Many perceive university libraries as geared towards teaching and learning, prioritizing undergraduates (RIN, 2007; Daniels, Darch and de Jager, 2010) and 'a dispensary of goods (books, articles) rather than a locus for badly needed, real-time professional support' (Jahnke, Asher and Keralis, 2012, 16). Libraries are currently moving into more specialized higher-end research support roles that are aligned with institutional concerns and have the potential to enable strategic repositioning on campus. Scholarly publishing is a growth area, with many American libraries now publishers of journals, monographs and conference proceedings, and well placed to lead experiments with open access business models (Crow et al., 2012). Bibliometric analysis is increasingly used to evaluate and manage research activities at institutional, departmental and individual level, creating opportunities for libraries to deliver valued support to senior research administrators, and input to grant applications and promotion cases (Corrall, Kennan and Afzal, 2013).

The library role most valued by researchers is apparently the traditional collection stewardship function, which now includes digital content as well as print material, along with the procurement and administration of electronic resources. There are positive, though less consistent, messages about institutional repository development: many researchers support the concept of open access to scholarship, but have not actually deposited their work, or used content from their own or other repositories (RIN, 2007; Schonfeld and Housewright, 2010). The role of librarians in information skills is also recognized, though more care may be needed to ensure support is geared towards 
researchers' needs and pitched at the right level (RIN, 2007, 2011). In addition, despite visiting them less frequently, many researchers continue to be inspired by the creative and contemplative atmosphere of research libraries, particularly valuing the 'scholarly nature' of library space (Gannon-Leary, Bent and Webb, 2008, 4), but noise levels from mobile phones and group work in contemporary library buildings often make working conditions no longer conducive to individual quiet study (RIN, 2007; Daniels, Darch and de Jager, 2010). Researchers also see the library as a place to access up-to-date technology (RIN, 2007).

\section{Current trends, implications and opportunities}

Looking ahead, the trends expected to have the biggest impact on libraries are changes already under way for more than a decade in scientific research and scholarly communication - specifically, the emergence of networked data-intensive science (also known as cyberscholarship and e-research) as the dominant research paradigm, and the parallel elevation of data, rather than publications, as the valued product of scientific enterprise (Michener, 2012). E-research developments have major implications for library activities in digital and data stewardship, digital and data reference and digital and data literacy. Data here can originate from observation, simulation or experiments; it can take many forms (such as text, numbers, audio, still and moving images), and relate to any discipline, including the arts and humanities (Martinez-Uribe, 2007; Williford and Henry, 2012).

The data revolution and corresponding revolution in scholarly communication and publishing will have an impact on the library comparable to the education revolution in the 1990s, which replaced 'sage-on-the-stage' pedagogy with student-centred resourcebased learning and enabled librarians to develop and professionalize their educational role as learning facilitators, learning advisers, instructional designers and teachers of information literacy (Breivik, 1999; Bewick and Corrall, 2010), and also reposition their services and spaces as 'learning resource centres', 'learning centres' and, latterly, 'information commons' or 'learning commons' (Roberts, 2007; Lewis, 2010; Weiner, Doan and Kirkwood, 2010). E-science uses high-capacity global networks to access very large-scale shared resources, including high-performance simulation, observation, computation and visualization equipment and massive distributed datasets. E-research has been described as 'collection-based science' (Beagrie, 2006, 5), highlighting potential synergies with traditional library activities and a clear opportunity for libraries to develop their research role from support service to project partner and more - 
though few researchers see the library as a research partner at present (Jahnke, Asher and Keralis, 2012).

While technically challenging and requiring a deeper understanding of research processes and workflows than other library activities, data management fits logically with established library responsibilities and in many ways simply extends the scope of existing activities; for example, teaching data discovery skills and citation practices as part of information literacy education, as well as incorporating data into collection development, repository management, metadata creation and digital preservation (Cox, Verbaan and Sen, 2012). Mandates from research funders for open access to datasets mean that institutional repositories and data curation are now required elements of university infrastructure that need professional management by a central service, and the library is the obvious candidate for this stewardship role. Data-intensive science is giving libraries the opportunity for a more visible role as a partner in the knowledge creation process, by contributing to obligatory data management plans, data description and preservation (Tenopir, Birch and Allard, 2012; Witt, 2012). As data management becomes the 'new statistics', students will need training in all aspects of the data life cycle so they can handle massive volumes of complex data and use new analytical and visualization tools to interpret underlying patterns and processes (Michener, 2012, 50). Libraries will accordingly need to build services and facilities around the knowledge creation cycle of scholarly research workflows (Jahnke, Asher and Keralis, 2012; Ohio State University Libraries, 2012).

University libraries are already offering or planning services to help researchers with data problems (Corrall, Kennan and Afzal, 2013). At Purdue University, subject librarians are dealing with data in their collection, instruction and reference activities (Witt, 2012), and also partnering three other research libraries, all working with experienced researchers, to develop training in data information literacy for science and engineering research students (Jahnke, Asher and Keralis, 2012). Librarians and researchers have both spotted the opportunity for spaces freed up by collections going virtual to be repurposed for research collaboration and computing facilities (Michener, 2012), particularly for research students and early career researchers who may not have their own labs (Jahnke, Asher and Keralis, 2012). Several US libraries have opened or are planning 'research commons' facilities as renovations or new builds designed to support interdisciplinary data-intensive scholarship, offering services in partnership with other campus units, to assist researchers in areas such as grant writing, research conduct, copyright and open access publishing; for example, the University of Washington Libraries (2010). 


\section{Future space and services}

The research commons model emerges as the preferred strategy globally for promoting library support for research. A consortium of research libraries in South Africa collaborated in an innovative programme to improve research support by creating new research commons facilities, along with customizable web-based research resources and advanced training for subject librarians (Daniels, Darch and de Jager, 2010). In the UK, the University of Warwick Library opened its Wolfson Research Exchange in 2009 as a highly visible dedicated research space in a prime location on campus, combining traditional quiet study places, with collaborative and social areas, in a technology-rich environment with mobile equipment that can be reconfigured for different types of meetings - from poster sessions, through project meetings and reading groups, to summer schools and academic conferences. Facilitating cross-discipline research interactions and 'fostering a sense of community' are key aims of the service, which includes events on topics such as funding opportunities, grant application tracking, data management, bibliometrics, journal impact, patents and spinout companies (Carroll, $2011,91)$. Some research commons facilities provide access to specialized hardware and software for data and textual analysis; others are collocated with digital humanities institutes and interdisciplinary research centres or offices (Ohio State University Libraries, 2012).

Commentators emphasize that researchers want and need physical facilities that are separate from undergraduates, because they are engaging in knowledge creation and production at a quite different level. Another clear message is the critical need for librarians to understand the day-to-day working contexts of the researchers they aim to support, including their academic ambitions, disciplinary differences, institutional imperatives and political pressures that drive or constrain their efforts. Partnerships, marketing and empathy emerge as key library requirements for delivering relevant and valued services (Webb, Gannon-Leary and Bent, 2007). The subject, reference and liaison librarian role is the traditional model used for supporting research in academic libraries (Holland, 2006), but has evolved in some institutions into the more specialized role of 'informationist' or 'information specialist in context' (Shipman, 2007), which requires deeper knowledge of the subject domain and its research methods to enable more extensive input to research projects. The 'embedded librarian' concept is a variant that similarly emphasizes closer engagement with stakeholders and location of assistance in academic departments or equivalent settings (Dewey, 2004; Shumaker, 2012). Embedded librarianship is also a potential model to support research data 
management, where a librarian is embedded into research group or specific research projects (Carlson and Kneale, 2011).

An interesting feature of emergent data management and bibliometric services is the way they are extending library service partnerships beyond typical partners in the information or learning commons model, through collaborations with research offices and graduate schools, and (to a lesser extent) planning departments, human resources and records management and legal services, and adding new dimensions to collaborations with technology services, including high-performance computing and eresearch units (Corrall, Kennan and Afzal, 2013). Partnerships between research libraries and external institutions to promote long-term preservation and access to scholarly resources are also becoming an essential dimension of stewardship responsibilities in the network world and liberating space for repurposing, through distributed reserve collections and collaborative storage facilities for low-use print journals and monographs, shared digital archives and open access repositories for digitized books and digital data (Boyle and Brown, 2010; Demas and Miller, 2012; Williford and Henry, 2012).

Future services for research will continue to focus on the library's stewardship responsibility, but emphasize a rich array of digital data. Collections will be planned and managed collaboratively through internal and external partnerships, but based on a mix of federated, licensed and open access resources with a greatly reduced physical presence in library buildings. Spaces for people and technology should be expanded and reconfigured to provide more visible, effective and efficient support for research across the institution by adopting the research commons model. Our vision of the research commons is a one-stop shared space-as-service facility for researchers, similar in its design philosophy and staffing model to leading examples of information and learning commons, which have demonstrated how careful and innovative user-centred design aligned to institutional needs and pedagogies can successfully integrate resources provided by the library into the working and social lives of students with support from other campus units (Lewis, 2010; Weiner, Doan and Kirkwood, 2010) and rebrand the library as a central, essential and vital facility.

The research commons should similarly reflect campus needs and priorities, including research methodologies and researcher preferences, but should be designed and managed by a different set of service partners, to accommodate more specialist hardware and software, and multi-professional teams with the research, subject and technical know-how to provide in-context end-to-end support for both discipline-based and interdisciplinary projects and programmes. Research offices and graduate schools 
have emerged as key partners for libraries delivering innovative higher-end research support, along with information compliance units and research computing teams in campus technology services (Carroll, 2011; Lyon, 2012; Corrall, Kennan and Afzal, 2013). The presence of staff from such units will provide complementary expertise and credibility for librarians moving into areas such as calculations of research impact indicators and guidance on data management planning for grant applications or peer review of online scholarship and publication advice for digital datasets after project completion (Williford and Henry, 2012; Witt, 2012). University presses, which are increasingly library-based operations, could also have a presence here, along with knowledge transfer and innovation units.

The overarching goal is to create a place that is viewed as a research facility - not a traditional library or learning centre - which offers expert help for all stages and phases of the research process from ideas generation, through problem definition, project design and bid writing, data acquisition, analysis and interpretation, to publication and archiving of findings. Repurposing one or more floors of a library building is one option, but is likely to be most successful if it is clearly differentiated from undergraduate facilities and has substantial physical presence of cognate services. A prominently positioned facility could also support the strategic objectives of many institutions to showcase their research to wider audiences, by hosting public lecture series, Café Scientifique meetings and citizen science events - another area envisaged as a future interest for libraries (Lyon, 2012; Williford and Henry, 2012).

Our proposed model is compatible with the current trend towards embedded librarianship (Dewey, 2004; Carlson and Kneale, 2011; Shumaker, 2012), which places information specialists with domain understanding in locations where they can anticipate and deliver point-of-need assistance geared to the work context. Dividing research liaison librarians' time between academic units and a central commons facility is more likely to be scalable and affordable than having liaison librarians wholly located in academic departments or schools. The design of user-centred high-tech expertly staffed research facilities on a collaborative space-as-service model will elevate libraries from invisible infrastructure to vital partners in the work of researchers. 


\section{References}

Aldrich, A. W. (2007) Following the Phosphorous Trail of Research Library Mission Statements into Present and Future Harbors, ACRL 13th National Conference, Baltimore, MD, March 29 - April 1, 2007, American Library Association, Association of College and Research Libraries, 304-16, www.ala.org/acrl/conferences/confsandpreconfs/national/baltimore/baltimore.

Beagrie, N. (2006) Digital Curation for Science, Digital Libraries, and Individuals, International Journal of Digital Curation, 1 (1), 3-16, www.ijdc.net/index.php/ijdc/article/viewFile/6/2

Bewick, L. and Corrall, S. (2010) Developing Librarians as Teachers: a study of their pedagogical knowledge, Journal of Librarianship and Information Science, 42 (2), 97-110.

Boyle, F. and Brown, C. (2010) The UK Research Reserve (UKRR): machinations, mayhem and magic, Interlending \& Document Supply, 38 (3), 140-6.

Breivik, P. S. (1999) Take II: information literacy - revolution in education, Reference Services Review, 27 (3), 271-5.

Carlson, J. and Kneale, R. (2011) Embedded Librarianship in the Research Context: navigating new waters, College \& Research Libraries News, 72, 167-70, http://crln.acrl.org/content/72/3/167.full.

Carroll, D. (2011) Fostering a Community of Scholars at the University of Warwick: the Wolfson Research Exchange, New Review of Academic Librarianship, 17, 78-95.

Corrall, S., Kennan, M. A. and Afzal, W. (2013) Bibliometrics and Research Data Management: emerging trends in library support for research, Library Trends, 61 (3), 636-74.

Cox, A., Verbaan, E. and Sen, B. (2012) Upskilling Liaison Librarians for Research Data Management, Ariadne, 70, www.ariadne.ac.uk/issue70/cox-et-al.

Crow, R., Ivins, O., Mower, A., Nesdill, D., Newton, M., Speer, J. and Watkinson, C. (2012) Library Publishing Services: strategies for success, final research report (Version 2.0), SPARC, http://wp.sparc.arl.org/lps/.

Daniels, W., Darch, C. and de Jager, K. (2010) The Research Commons: a new creature in the library, Performance Measurement and Metrics, 11 (2), 116-30.

Demas, S. and Miller, M. E. (2012) Rethinking Collection Management Plans: shaping collective collections for the 21st century, Collection Management, 37 (3-4), 16887. 
Dewey, B. I. (2004) The Embedded Librarian: strategic campus collaborations, Resource Sharing \& Information Networks, 17 (1/2), 5-17.

Gannon-Leary, P., Bent, M. and Webb, J. (2008) A Destination or a Place of Last Resort?

The research library of the future, its users and its librarians, Library and Information Research, 32 (101), 3-14.

www.lirgjournal.org.uk/lir/ojs/index.php/lir/article/view/65/112.

Holland, M. (2006) Serving Different Constituencies: researchers. In Dale, P., Holland, M. and Matthews, M. (eds) Subject Librarians: engaging with the learning and teaching environment, Ashgate, 131-47.

Jahnke, L. M., Asher, A. and Keralis, S. (2012) The Problem of Data, Council on Library and Information Resources \& Digital Library Federation, www.clir.org/pubs/reports/pub154/pub154.pdf.

Lewis, M. (2010) The University of Sheffield Library Information Commons: a case study, Journal of Library Administration, 50 (2), 161-78.

Lyon, L. (2012) The Informatics Transform: re-engineering libraries for the data decade, International Journal of Digital Curation, 7 (1), 126-38, www.ijdc.net/index.php/ijdc/article/view/210/279.

MacColl, J. and Jubb, M. (2011) Supporting Research: environments, administration and libraries, OCLC Research, www.oclc.org/resources/research/publications/library/2011/2011-10.pdf.

Martinez-Uribe, L. (2007) Digital Repository Services for Managing Research Data: what do Oxford researchers need?, IASSIST Quarterly, 31 (3-4) 28-33, www.iassistdata.org/downloads/iqvol313martinez.pdf.

Michener, W. (2012) Five New Paradigms for Science and an Introduction to DataONE, Educause Review, 47 (2), 50-1, http://net.educause.edu/ir/library/pdf/ERM1225.pdf.

OCLC (2010) Perceptions of Libraries, 2010: context and community, OCLC Online Computer Library Center Inc, www.oclc.org/reports/2010perceptions.htm.

Ohio State University Libraries (2012) Overview of Research Commons in Academic Libraries: a white paper, http://library.osu.edu/staff/administrationreports/ResearchandEducation/ResearchCommonsVision.pdf.

RIN (2007) Researchers' Use of Academic Libraries and Their Services: a report commissioned by the Research Information Network and the Consortium of Research Libraries, www.rin.ac.uk/system/files/attachments/Researcherslibraries-services-report.pdf. 
RIN (2011) The Role of Research Supervisors in Information Literacy, Research Information Network, www.rin.ac.uk/news/role-research-supervisorsinformation-literacy.

Roberts, R. L. (2007) The Evolving Landscape of the Learning Commons, Library Review, 56 (9), 803-10.

Schonfeld, R. C. and Housewright, R. (2010) Faculty Survey 2009: key strategic insights for libraries, publishers, and societies, Ithaka Strategic Consulting and Research, www.sr.ithaka.org/research-publications/faculty-survey-2009.

Scott, J. C. (2006) The Mission of the University: medieval to postmodern transformations, Journal of Higher Education, 77 (1), 1-39.

Shipman, J. (2007) Informationists or Information Specialists in Context (ISIC): six years after conception, IFLA Journal, 33 (4), 335-9, http://archive.ifla.org/V/iflaj/IFLAJournal-4-2007.pdf.

Shumaker, D. (2012) The Embedded Librarian: innovative strategies for taking knowledge where it's needed, Information Today.

Tenopir, C., Birch, B. and Allard, S. (2012) Academic Libraries and Research Data Services: current practices and plans for the future, An ACRL white paper, Association of College \& Research Libraries, www.ala.org/acrl/sites/ala.org.acrl/files/content/publications/whitepapers/Tenop ir_Birch_Allard.pdf.

University of Washington Libraries (2010) Research Commons to Open in Allen Library, UW Libraries e-News, September, www.washington.edu/alumni/partnerships/libraries/201009/commons.html.

Webb, J., Gannon-Leary, P. and Bent, M. (2007) Providing Effective Library Services for Research, Facet Publishing.

Weiner, S. A., Doan, T. and Kirkwood, H. (2010) The Learning Commons as a Locus for Information Literacy, College \& Undergraduate Libraries, 17 (2), 192-212.

Williford, C. and Henry, C. (2012) One Culture: computationally intensive research in the humanities and social sciences, a report on the experience of first respondents to the digging into data challenge, Council on Library and Information Resources, www.clir.org/pubs/reports/pub151/pub151.pdf.

Witt, M. (2012) Co-designing, Co-developing, and Co-implementing an Institutional Data Repository Service, Journal of Library Administration, 52 (2), 172-88. 